\title{
MORPHOLOGICAL CHANGES IN TISSUES OF ORGANS IN RATS WITH ARTERIAL HYPERTENSION (SHR) WITH TREATMENT OF HYPOTENSIVE MEDICINES (WITH RAMIPRIL AND CANDESARTAN) IN COMBINATION WITH CORVITIN
}

\author{
A. Marushchak, Y. Rogovyy, V. Doroshko, V. Shvets, T. Savchuk
}

\begin{abstract}
На сьогоднішній день артеріальна гіпертензія (АГ) - найпоширеніше серцево-судинне захворювання, яке є найбільш частою причиною інвалідизації населення внаслідок високого ризику розвитку таких ускладнень, як сериева недостатність, ішемічна хвороба серия, інсульт. Характер морфологічних проявів гіпертонічної хвороби залежить від тривалості і важкості перебігу, але гіпертензія запускає каскад патологічних змін уже при легкому перебігу хвороби і супроводжується порушенням структури найбільш чутливих до коливання артеріального тиску органів (мозок, серие, нирки). Постійно триває пошук нових препаратів, які не тільки знижують артеріальний тиск, а володіють політропними ефектами. На першому місиі стоїть кардіопротекція, яка трунтується на засадах постійного контролю за оксигенацією міокарда і процесами метаболізму. Останнім часом увагу дослідників привертають біофлавіноїди, а саме корвітин, який має антиоксидантні, протиапоптичні, протизапальні властивості. Питання впливу корвітину в комбінованій терапії з гіпотензивними препаратами при лікуванні артеріальної гіпертензї вивчено недостатньо, щуо визначає актуальність і мету нашого дослідження.
\end{abstract}

Матеріали та методи. Дослідження проведено на спонтанно-гіпертензованих щурах SHR. Щури розділені на 9 груп. Дослідним групам тварин SHR вводили раміприл в дозі 0,5 мг /кг, кандесартан - 0,4мг /кг, а також проводили комбіновану терапію раміприл і корвітин, кандесартан $і$ корвітин. Препарати вводили 1 раз на день протягом 7 днів з їжею (для короткочасної терапії) і протягом 21 дня (для тривалої mepanii).

Для оцінки морфологічних змін серия, нирок, печінки використовували заморожені поперечні зрізи товщиною 10 мкм, які зафарбовували за методом Рамоновского-Гімзе.

Результати дослідження. Корвітин при застосуванні $і$ з раміприлом $і$ з кандесартаном мав протекторний вплив на досліджувані структури органів-міменей: міокард шлуночків, кіркову речовину нирки, гепатоцити. Але кардіопротекторний ефект корвітину відмічений в тканині міокарда лівого шлуночка при довготривалій комбінованій терапії з кандесартаном був більш суттєвим і характеризується зникненням ознак гідропічної вакуолізації кардіоміочитів. Комбінована терапія гіпотензивними препаратами з корвітином зменшувало ступінь атрофії ниркових клубочків, найбільша ефективність досягалась довготривалою терапією. Зміни в тканині печінки при комбінацї препаратів також мали позитивну динаміку.

Висновки. Поєднана терапія гіпотензивними препаратами і корвітином суттєво покращує морфологічну картину в досліджуваних структурах не тільки за рахунок зниження артеріального тиску, а обумовлена і плейотропними ефектами корвітину.

Ключові слова. Артеріальна гіпертензія, кандесартан, раміприл, корвітин

Copyright (C) 2020, A. Marushchak, Y. Rogovyy, V. Doroshko, V. Shvets, T. Savchuk. This is an open access article under the CC BY license (http://creativecommons.org/licenses/by/4.0).

\section{Introduction}

Hypertension is one of the leading health problems worldwide. Cardiovascular mortality in half of all cases is associated with hypertension, as well as its complications such as stroke, coronary heart disease, and heart failure. Despite significant advances in the treatment of this pathology, it remains the main cause of adverse prognosis [1].

The pathogenesis of heart failure on the background of hypertension is damage to cell membranes, which is associated with the formation of reactive oxygen species (ROI), activation of lipid peroxidation (LPO), activation of pathological cytokines, impaired endothelial function [1,2] and apoptosis.
An important link in the development of the pathological process is the activation of lipoxygenases and impaired nitric oxide synthesis, which is accompanied by increased production of ROI, especially peroxynitrite. Depending on the stage of hypertension, a whole cascade of pathomorphological changes with hypertrophy of the muscular layer and elastic structures develops. Liver cells are also sensitive to the development of oxidative stress, due to their biochemical and physiological properties: high energy activity and rapid depletion of antioxidant defense system (AOD) [3, 4]. The kidneys play a leading role in the regulation of blood pressure due to the excretion of water and sodium, secretion of renin, prostaglandins. Prolonged hypertension is ac- 
companied by narrowing of the fetus arterioles, enhancement of water reabsorption processes in the distal tubules $[5,6]$.

Effective drugs in the treatment of $\mathrm{AH}$ are inhibitors of angiotensin-converting enzyme (ACE) ramipril and antagonist of angiotensin receptor candesartan [7, 8]. Reducing blood pressure to the normal range is essential to prevent complications of cardiovascular disease, but it is important to find new drugs that have a polytropic effect and not only normalize blood pressure, but also have protective effects on tissues that have undergone pathological changes $[9,10]$. According to the literature, corvitin, which is a water-soluble complex of bioflavinoid quercetin with polyvinylpyrrolidine, has cardiotonic, antitumor, hypolipidemic, anti-inflammatory, antimicrobial, hypoglycemic action [11, 12].

Having antioxidant properties, corvitin lowers the level of LPO, acting as traps for ROI, has a inhibitory effect on the activity of enzymes involved in phospholipid degradation. Corvitin prevents intracellular influx of calcium ions into platelets, thereby reducing their aggregation. Effect on production of nitric oxide and inhibition of protein kinase $\mathrm{C}$ activity causes coronary vasodilating action $[8,9]$. The combination of such properties makes it possible to apply the drug as a protector under conditions of development of pathological changes in the systems and organs against the background of arterial hypertension.

To date, the use of corvitin in combination therapy with antihypertensive drugs has not been sufficiently studied, which determines the relevance and novelty of our study.

The aim of our study was to determine the effect of combination therapy with ramipril and corvitin, candesartan and corvitin on morphological changes in the heart, liver, and kidney, which were recorded in the rat with spontaneous hypertension (SHR).

\section{Planning (methodology) of research}

For the successful correction of arterial hypertension in the early stages of pathological changes, it is important to study the mechanisms of development of the pathological process. In spontaneously hypertensive animals, there is persistent hypertension that results from structural and functional changes in blood vessels that are similar to molecular mechanisms in the development of hypertension in humans. This led to the selection of a group of rats with hypertension.

Effective drugs in the treatment of $\mathrm{AH}$ are inhibitors of angiotensin converting enzyme (ACE) ramipril and antagonist of angiotensin receptor candesartan. Recent studies have found that taking candesartan and ramipril reduces the morphological manifestations of the pathological process, and the combination of these drugs with corvitin promotes the restoration of organ structure.

Our research included the following steps:

1. Inclusion in the experiment of rats with hypertension (SHR).

2. Therapy of arterial hypertension of SHR rats with ramipril and candesartan for short and long period.

3. Combination therapy with antihypertensive drugs and drugs that have antioxidant properties corvitin.
4. Conducting morphological studies of the most vulnerable to hypertension organs: kidney, liver, heart.

\section{Materials and methods}

The study was conducted from 2017 to 2019 on 64 rats with spontaneous hypertension (SHR) weighing 180.0-220.0 g (kennel of laboratory animals "Biomodelservice", Kyiv). During the acclimatization period after transportation ( 2 weeks), the animals were in vivarium conditions at $20-25^{\circ} \mathrm{C}$, humidity not more than $50 \%$, natural light, in standard plastic cages on a standard diet [13]. The study was conducted in 9 groups of animals: the control group consisted of spontaneously hypertensive animals SHR, which was injected with saline $0.9 \%$ sodium chloride; the first experimental group included animals that received short-term treatment ( 7 days) with ramipril, the second experimental group - animals that received long-term (21 days) therapy with ramipril, the third experimental group - short-term therapy (7 days) with candesartan, the fifth group - long-term candesartan therapy, the sixth experimental group - combination therapy with corvitin and ramipril (7 days), and the seventh experimental group - a combination of corvitin and ramipril (21 days), eighth and ninth experimental groups - short and long-term combination therapy with candesartan and corvitin.

Using the method of species sensitivity by Yu. R. Rybolovlev and using the method of calculating the coefficient, we calculated the dose for humans per dose for rats: dose for humans $\mathrm{mg} / \mathrm{kg} / 0.45=\mathrm{X} \mathrm{mg} / \mathrm{kg} / 1.89$. we determine that the conditional therapeutic dose for rats: candesartan is $0.5 \mathrm{mg} / \mathrm{kg}$, ramipril - $0.4 \mathrm{mg} / \mathrm{kg}$, corvitin $50 \mathrm{mg} / \mathrm{kg}$ [14].

In the SHR study group, ramipril was administered at a dose of $0.5 \mathrm{mg} / \mathrm{kg}$ (Hexal AG Germany), candesartan $0.4 \mathrm{mg} / \mathrm{kg}$ (Ranbaxy Laboratories Limited), corvitin (Borshchahivskiy CPP) at a dose of $50 \mathrm{mg} / \mathrm{kg}$, corresponding to the range daily doses for humans with the calculation of the conversion factor for rats. The compared drugs were administered once daily for 7 days with food (for short-term therapy) and for 21 days (for long-term therapy). The control group of animals of the SHR series was injected $0.9 \%$ sodium chloride solution in an equivalent volume $(0.2 \mathrm{ml} / 200 \mathrm{~g})$ intragastrically every day. Combination therapy with corvitin was performed for 7 days.

To assess the morphological changes of the heart, kidneys and liver we used frozen cross-sections with a thickness of $10 \mu \mathrm{m}$, which were painted according to the method of Ramonovsky-Gimze using hemotoxylin eosin. Histological preparations were studied using a Biolam Lomo C11 optical microscope, assessing the appearance and size of cells, the intensity of staining, the shape and structure of the nucleus, cytolemy and cell organelles [9].

Experimental studies and animal euthanasia were conducted in accordance with the international principles of the European Convention for the Protection of Vertebrate Animals (Strasbourg, 1985).

\section{Research results}

In the control group of SHR animals, kidney atrophy of renal glomeruli was expressed $9.13 \pm 0.12 \%$, which is manifested by a decrease in their size, due to the 
decrease in the number of cells and their dense location, in other zones hypertrophy of the glomeruli is observed (Fig. 1). In the arteries and arterioles there is hypertrophy of the walls due to the number of leiomyocytes with thickening of the media (Fig. 2), $22.43 \pm 0.18 \%$ of leiomyocytes have signs of hydropic vacuolation. Vascular endothelial cells at different stages of desquamation. The formation of polygonal cells with dark large nuclei is observed, which accompanies the defeat of the epithelium of the tortuous tubules (Fig. 3).

In the myocardium of the control group, there was hypertrophy of the walls of the left ventricle and interventricular septum. The size of cardiomyocytes increased with deformation of muscle fibers. In $15.14 \pm 0.13 \%$ of cardiomyocytes was hydrocephalous swelling, and in $5.36 \pm 0.12 \%$ - basophilic degeneration (Fig. 4). In the liver of the control group of animals, the reverse swelling was $94.45 \pm 0.34 \%$ of hepatocytes, the hydropic swelling was centrollobular (III acinus zone), and the hydropic vacuolation was peripheral globular (I acinus zone) (Fig. 5).

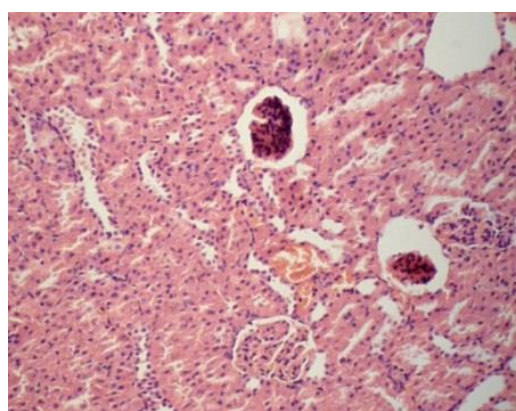

Fig. 1. Cortical substance of rat kidney. SHR rat control group. Atrophied glomeruli, other glomeruli in a state of

hypertrophy. Hematoxylin and eosin staining. Eye. $10 \times$. Lens. $10 \times$.

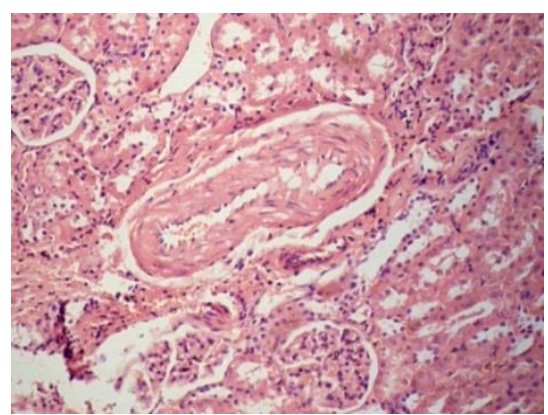

Fig. 2. Cortical substance of rat kidney. SHR rat control group. Hypertrophic walls of vessels. Staining with hematoxylin and eosin. Eye. 10×. Lens. 10×.

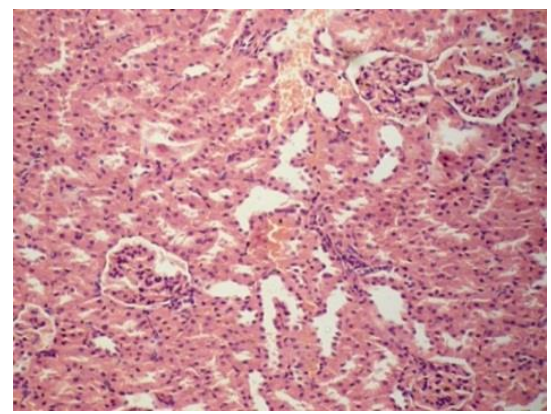

Fig. 3. Cortical substance of SHR rat kidney. Incomplete renal tubules. Staining with hematoxylin and eosin.

Eye. $10 \times$. Lens. $10 \times$.

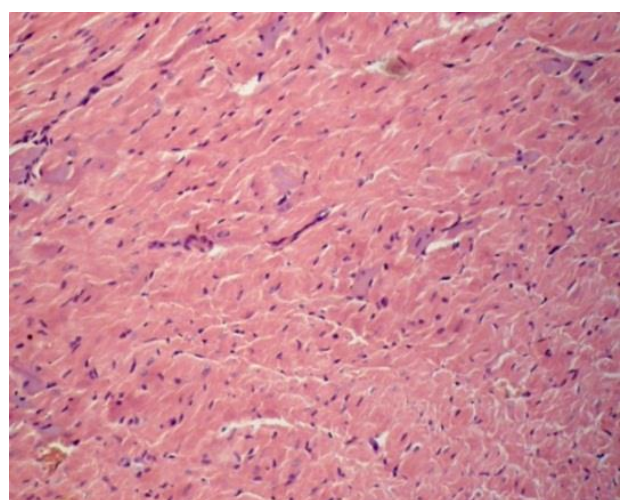

Fig. 4. Ventricles of rat myocardium. SHR rat control group. Myocardial wall hypertrophy. Hematoxylin and eosin staining. Eye. 10×. Lens. 10×.

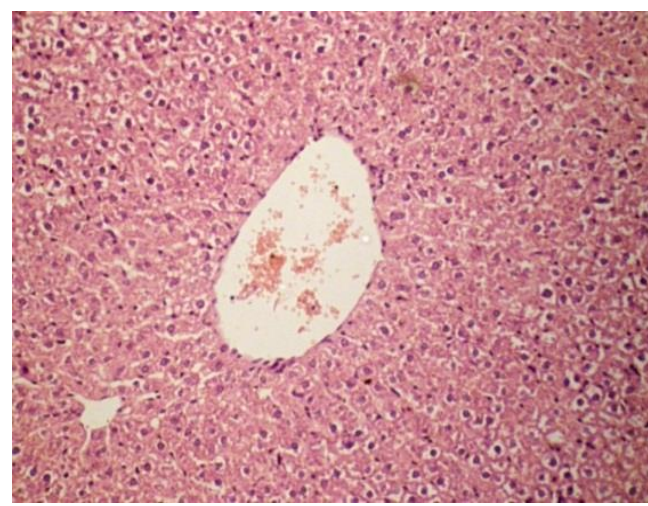

Fig 5. Rat liver. SHR rat control group. Hydropic swelling of hepatocytes and hydropic vacuolation. Hematoxy-

lin and eosin staining. Eye. 10×. Lens. 10×.

Short-term ramipril treatment deepened the area of atrophy to $8.62 \pm 0.17 \%$ of renal tubules and significantly reduced hypertrophy of the arterial walls and arterioles at 21 days of treatment. Short-term candesartan treatment reduced the area of hypertrophy of the artery media and leiomyocyte arterioles with signs of hydropic vacuolation 4 times compared with the control group. A similar trend was observed in long-term treatment with the absence of leiomyocytes with signs of hydropic vacuolation.

For myocardium, the use of ramipril 3.5 times reduced the degree of hydropic swelling of cardiomyocytes, and with prolonged treatment, no signs of hydroponic swelling were present. Basophilic degeneration decreased 6.25 times and duration of treatment was not significant. Similar changes of positive dynamics were demonstrated by candesartan already at short-term treatment with absence of hydropic vacuolation of cardiomyocytes at long-term treatment. All the studied changes had a high degree of probability.

In the liver, the area of back swelling was reduced and with short and long-term treatment up to $42.35 \pm 0.30 \%$ of hepatocytes. Only long-term treatment with candesartan had a positive effect on liver tissue and a mild form was noted - hydropic swelling [9, 10].

Combination therapy with ramipril and corviton significantly improved the morphological result in all study structures compared with controls and animals treated with ramipril and candesartan alone in short and long period. 
The combination of ramipril and corvitin reduced the area of atrophy of the renal glomeruli to $4.55 \pm 0.15 \%$ at 7 days of treatment and to $2.13 \pm 0.15 \%$ at 21 days (Fig. 6). Hypertrophy of the artery walls and arterioles decreased, and signs of hydropic vacuolation were observed in $12.46 \pm 0.12 \%$ and $11.24 \pm 0.11 \%$ leiomyocytes, respectively, in short and long-term treatment, respectively (Fig. 6). The number of vascular endothelial cells with signs of desquamation decreased significantly (Fig. 7). Combined therapy of candesartan and corvitin in the renal arteries and arterioles led to a decrease in the hydropic vacuolation of leiomyocytes to $4.24 \pm 0.08 \%$ with long-term treatment, with no renal glomerular atrophy (Fig. 8). Morphological changes in the kidney during combination therapy with corvitin had a high degree of probability.

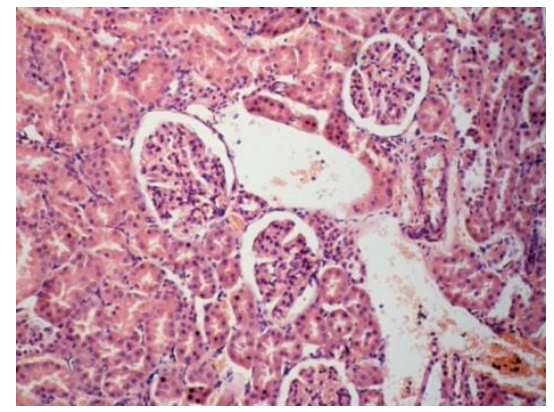

Fig. 6. Cortical substance of the SHR rats' kidney. Combined long-term therapy (ramipril and corvitin). Minor atrophy of the renal tubules. Staining with hematoxylin and eosin. Eye. 10×. Lens. 10×.

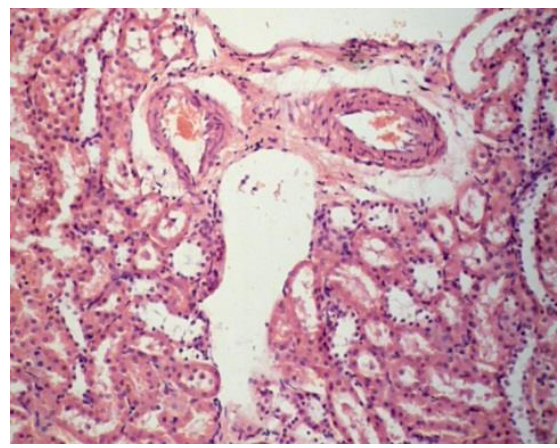

Fig. 7. Cortical substance of the SHR rats' kidney. Combined long-term therapy (ramipril and corvitin). There are no signs of endothelial cells with desquamation.

Staining with hematoxylin and eosin. Eye. $10 \times$. Lens. $10 \times$.

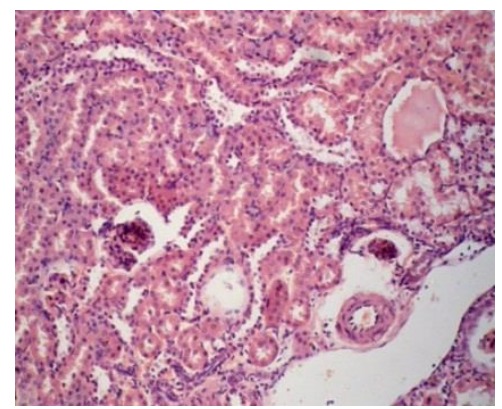

Fig. 8. Cortical substance of the SHR rats' kidney. Combined long-term therapy (candesartan and corvitin).

There is no atrophy of the renal glomeruli. Staining with hematoxylin and eosin. Eye. 10×. Lens. 10×.
In the myocardium, the use of ramipril and corvitin 4.7 times reduced the degree of hydropic swelling of cardiomyocytes, and with prolonged treatment, signs of hydropic swelling were absent (Fig. 9). Basophilic degeneration decreased 6.25 times and duration of treatment was not significant. Combination therapy of candesartan and corvitin, starting with short-term treatment, showed no signs of hydrophilic vacuolization and reduced basophilic degeneration 11.2 times (Fig. 10). The obtained changes were reliable.

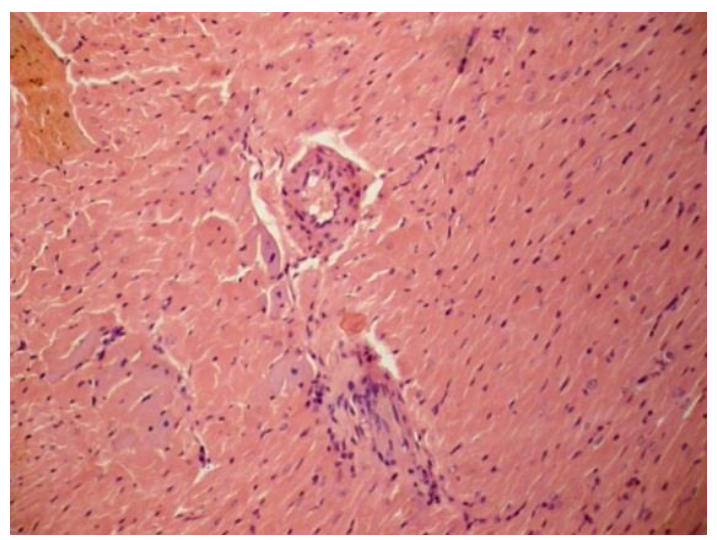

Fig. 9. SHR rat ventricular myocardium. Combined longterm therapy (ramipril and corvitin). Staining with hematoxylin and eosin. Eye. 10×. Lens. 10×.

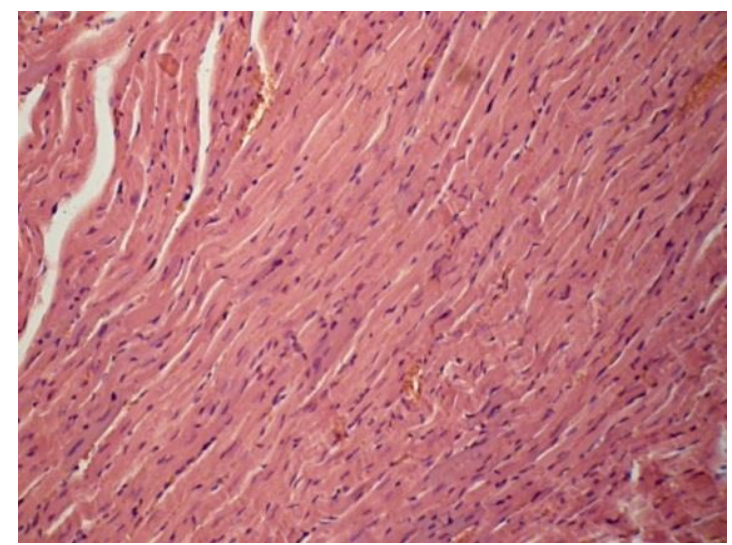

Fig. 10. SHR rat ventricular myocardium. Combined long-term therapy (candesartan and corvitin). Staining with hematoxylin and eosin. Eye. 10×. Lens. 10×.

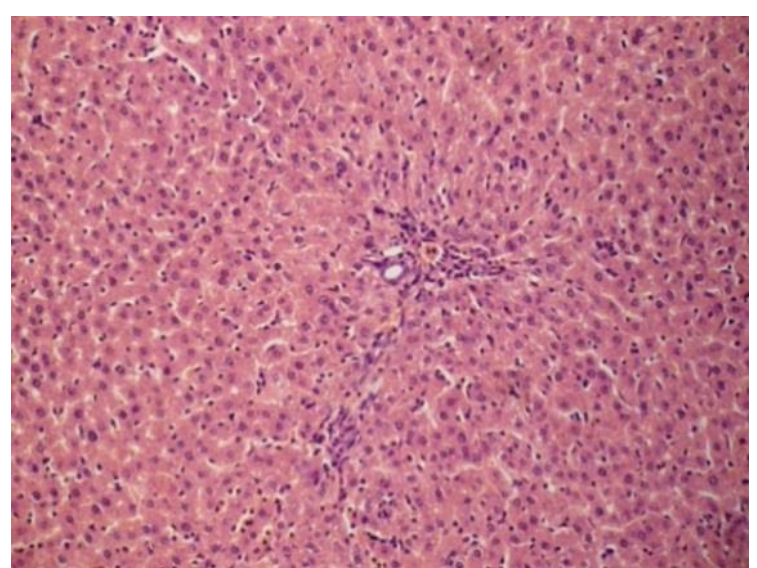

Fig. 11. SHR rat liver. Combined long-term therapy (ramipril and corvitin). Staining with hematoxylin and eosin. Eye. $10 \times$. Lens. $10 \times$. 


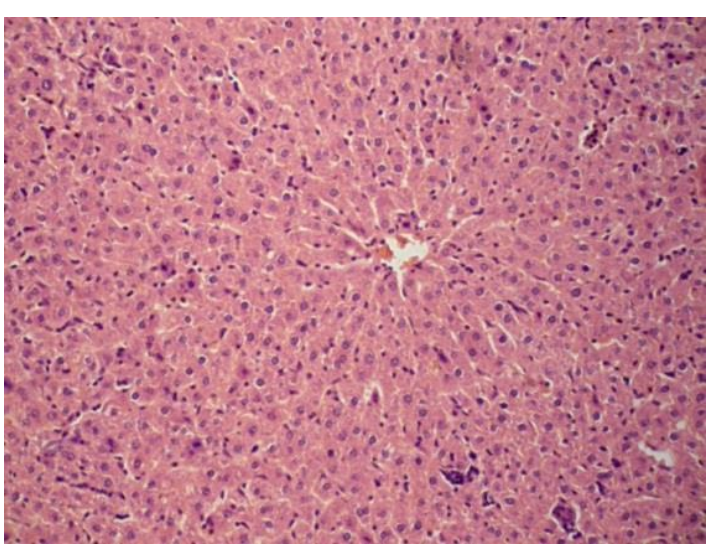

Fig. 12. SHR rat liver. Combined long-term therapy (candesartan and corvitin). Staining with hematoxylin and eosin. Eye. $10 \times$. Lens. $10 \times$.

In the liver, corvitin and ramipril with a high degree of likelihood reduced the swelling area both with short and long-term treatment to $31.34 \pm 0.32 \%$ of hepatocytes (Fig. 11). Long-term treatment with corvitin and candesartan had a positive effect on liver tissue with mild signs of hydropic swelling (Fig. 12) [9, 10].

\section{Discussion of research results}

The obtained data showed that the use of highprobability corvitin enhances the effects of antihypertensive drugs and improves the morphological picture in the studied structures compared with the control group and in the treatment with ramipril and candesartan. The greatest protective effect of corvitin was observed in the tissue of the left ventricular myocardium with long-term therapy with corvitin and candesartan with no signs of hydropic vacuolation of cardiomyocytes [13]. Increased blood pressure causes hypertrophy of the left ventricle. The positive effect of ramipril in combination with corvitin is a consequence of the stimulation of endothelium production of nitric oxide by enhancing the production of bradykinin and by suppressing the oxidative stress caused by RAAS activity. Endothelial production of nitric oxide plays a key role in ensuring homeostasis of the vascular system, regulating the size of the lumen of the vessels $[14,15]$. Treatment with ramipril leads to a decrease in left ventricular hypertrophy $[16,17]$.

It is known from the literature that SHR rats have increased renal production of angiotensinogen, which leads to increased levels of ABP, hypertension and kidney damage $[13,16]$. The combined effect of corvitin and ramipril on the kidneys reduced the degree of atrophy of the renal glomeruli with no pathological process when combining candesartan and corvitin with long-term treatment $[18,19]$. Ramipril contributes to the normaliza- tion of systemic blood pressure and increased blood flow to the kidneys, and in combination with corvitin enhances positive dynamics [20]. Candesartan reduces the excretion of total protein in the urine, prevents sclerosis of the glomeruli of SHR rats. Combined therapy with corvitin minimizes the effects of a pathological process with a high degree of likelihood. Changes in liver tissue with the combination of drugs had a positive dynamics but did not approach the physiological norm.

Study limitations. Study reflects only morphological changes and do not allow quantitative assessment of functional changes in the studied structures.

Prospects for further research. The conducted experiments of combined therapy of hypertension in SHR rats showed that the use of corvitin promotes the restoration of the structure of the studied organs. The conducted researches open a perspective direction of studying the effect of combination therapy with antihypertensive drugs with corvitin on the state of the prooxide-antioxidant system, on the reaction of the aggregate state of the blood for a comprehensive study of the effect of therapeutic drugs.

\section{Conclusions}

Ramipril exacerbated pathomorphological changes in the tissues of the kidney and ventricles, and its toxic effects on the liver were noted.

Long-term therapy with ramipril reduced 2.99 times the hypertrophy of the walls of the arteries and arterioles of the renal glomeruli. Corvitine combination therapy maintained the positive dynamics of morphological structure restoration and offset the negative effects of ramipril on renal tubule atrophy.

Candesartan contributed to the regression of the hydropic swelling of cardiomyocytes. Combination therapy with corvitin helped to restore the structure of the organ.

Continuous therapy with candesartan and corvitin completely restored the structure of the walls of the arteries and arterioles of the renal glomeruli and led to the complete restoration of these changes. Monotherapy with candesartan - the drug had almost no effect on atrophy of the renal glomeruli, and combination therapy restored the structure of the microcirculatory bed.

Combination therapy with ramipril and candesartan in combination with corvitin reduced the degree of reversible swelling of hepatocytes.

In most studies it has been shown that the beneficial effects of antihypertensive drugs are not only associated with a decrease in blood pressure, but are more due to the pleiotropic effects of combination therapy.

\section{References}

1. Barteková, M., Šimončíková, P., Fogarassyová, M., Ivanová, M., Okruhlicová, L., Tribulová, N. et. al. (2015). Quercetin Improves Postischemic Recovery of Heart Function in Doxorubicin-Treated Rats and Prevents Doxorubicin-Induced Matrix Metalloproteinase-2 Activation and Apoptosis Induction. International Journal of Molecular Sciences, 16 (12), 8168-8185. doi: http://doi.org/10.3390/ijms16048168

2. Sheik Uduman, M. S. T., Reddy, R. B., Punuru, P., Chakka, G., Karunakaran, G. (2016). Protective Role of Ramipril and Candesartan against Myocardial Ischemic Reperfusion Injury: A Biochemical and Transmission Electron Microscopical Study. Advances in Pharmacological Sciences, 2016, 1-7. doi: http://doi.org/10.1155/2016/4608979

3. Gurevich, M. A., Kuzmenko, N. A. (2017). Porazhenie serdca pri arterialnoi gipertenzii. Metody vozdeistviia na gipertenziiu i sokratitelnuiu disfunkciiu. Consilium Medicum, 19 (1), 88-92. 
4. Fusi, F., Trezza, A., Tramaglino, M., Sgaragli, G., Saponara, S., Spiga, O. (2020). The beneficial health effects of flavonoids on the cardiovascular system: Focus on K+ channels. Pharmacological Research, 152, 104625. doi: http://doi.org/10.1016/j.phrs. 2019.104625

5. Zharynova, V. Yu., Parasiuk, E. Y., Samots, Y. A. (2016). Vozmozhnosty povishenyia effektyvnosty antyhypertenzyvnoi terapyy: rol donatorov oksyda azota. Zdorovia Ukrainy, 1 (44), 45-46.

6. Tolparov, G. V. (2016) Vliianie blokatorov renin-angiotenzin-aldosteronovoi sistemy na funkcionalnoe sostoianie pravogo zheludochka pri infarkte miokarda perednei stenki levogo zheludochka. Kubanskii nauchnii medicinskii vestnik, 3 (158), 126-129.

7. Zhuravleva, D. A. (2009). Modeli arterialnoi gipertenzii. Spontanno-gipertenzivnye krysy. Kunstkamera, 15 (6), 721-722.

8. Bartekova, M., Radosinska, J., Pancza, D., Barancik, M., Ravingerova, T. (2016). Cardioprotective Effects of Quercetin Against Ischemia-Reperfusion Injury Are Age-Dependent. Physiological Research, 65 (1), $101-107 . \quad$ doi: http://doi.org/10.33549/physiolres.933390

9. Mahalias, V. M., Mikhieiev, A. O., Rohovyi, Yu. Ye. et. al. (2001). Suchasni metody eksperymentalnykh ta klinichnykh doslidzhen tsentralnoi naukovo-doslidnoi laboratoriii Bukovynskoi derzhavnoi medychnoi akademii. Chernivtsi, 42.

10. Moibenko, A. A., Parkhomenko, A. N. (2015). Effektivnost vodorastvorimoi formy kvercetina (Korvitina) pri lechenii ostrogo koronarnogo sindroma s elevaciei segmenta ST. Available at: http://health-ua.com/article/671.html

11. Parkhomenko, A. N., Kozhukhov, S. N. (2014). Rezultaty otkrytogo randomizirovannogo issledovaniia po izucheniiu perenosimosti i effektivnosti preparata Korvitin u pacientov s zastoinoi serdechnoi nedostatochnostiu i sistolicheskoi disfunkciei levogo zheludochka. Ukrainskii medichnii chasopis, 4 (102), VII/VIII.

1. 12 Zemlyaniy, Y. V. (2014). Dynamics of structural and functional changes of the heart and the levels of GDF 15 and NTproBNP on the candesartan and ramipril therapy in patients with heart failure with preserved ejection fraction after myocardial infarction on the background of arter. Zaporozhye Medical Journal, 2, 13-17. doi: http://doi.org/10.14739/2310-1210.2014.2.25232

12. Forner, D., Kulai, T., Arnason, T., Gruchy, E. S., MacLeod, M. (2017). Ramipril-associated cholestasis in the setting of recurrent drug-induced liver injury. Gastroenterol Hepatol Bed Bench, 10 (2), 143-146.

13. Oyagbemi, A. A., Omobowale, T. O., Ola-Davies, O. E., Asenuga, E. R., Ajibade, T. O., Adejumobi, O. A. et. al. (2018). Quercetin attenuates hypertension induced by sodium fluoride via reduction in oxidative stress and modulation of HSP 70/ERK/PPAR $\gamma$ signaling pathways. BioFactors, 44 (5), 465-479. doi: http://doi.org/10.1002/biof.1445

14. Chen, X., Li, H., Wang, Z., Zhou, Q., Chen, S., Yang, B. et. al. (2020). Quercetin protects the vascular endothelium against iron overload damages via ROS/ADMA/DDAH II/eNOS/NO pathway. European Journal of Pharmacology, 868, 172885. doi: http://doi.org/10.1016/j.ejphar.2019.172885

15. Gaponova, T. I., Kobeliackii, Iu. Iu., Panchenko, G. V. (2015). Rol korvitina i latrena v profilaktike i terapii reperfuzionnogo sindroma pri rekonstruktivnykh operaciiakh u pacientov s khronicheskoi ishemiei nizhnikh konechnostei. Medicina neotlozhnykh sostoianii, 2 (65), 88-92.

16. Zhyliaiev, S. O., Shtryhol, S. Yu., Zhyliaev, S. A., Shtryhol, S. Yu. (2013). Tserebroprotektyvna aktyvnist korvitynu ta lipoflavonu pry kombinatsii hostroi alkoholnoi intoksykatsii ta cherepno-mozkovoi travmy v eksperymenti. Pytannia eksperymentalnoi ta klinichnoi medytsyny, 17 (1), 93-103.

17. Douros, A., Kauffmann, W., Bronder, E., Klimpel, A., Garbe, E., Kreutz, R. (2013). Ramipril-Induced Liver Injury: Case Report and Review of the Literature. American Journal of Hypertension, 26 (9), 1070-1075. doi: http://doi.org/10.1093/ajh/hpt090

18. Khanal, M. K., Dhungana, R. R., Bhandari, P., Gurung, Y., Paudel, K. N. (2017). Prevalence, associated factors, awareness, treatment, and control of hypertension: Findings from a cross sectional study conducted as a part of a community based intervention trial in Surkhet, Mid-western region of Nepal. PLOS ONE, 12 (10), e0185806. doi: http://doi.org/10.1371/journal.pone.0185806

19. Vrolijk, M. F., Essen, H., Opperhuizen, A., Bast, A., Janssen, B. J. (2020). Haemodynamic effects of the flavonoid quercetin in rats revisited. British Journal of Pharmacology. doi: http://doi.org/10.1111/bph.14955

Received date 10.01.2020

Accepted date 05.02.2020

Published date 29.02.2020

Alena Marushchak, Assistant, Department of Pathological Physiology, Higher State Educational Institution of Ukraine «Bukovinian State Medical University», Teatralna sq., 2, Chernivtsi, Ukraine, 58002

E-mail: marushakaliona@ukr.net

Yuriy Rogovyy, MD, Professor, Department of Pathological Physiology, Higher State Educational Institution of Ukraine «Bukovinian State Medical University», Teatralna sq., 2, Chernivtsi, Ukraine, 58002

E-mail: pathophysiology@bsmu.edu.ua

Valentyn Shvets, Doctor of Biological Sciences, Professor, Department of Physiology, Higher State Educational Institution of Ukraine «Bukovinian State Medical University», Teatralna sq., 2, Chernivtsi, Ukraine, 58002 E-mail: physiology@bsmu.edu.ua

Volodymyr Doroshko, PhD, Associate Professor, Department of Pathological Physiology, Higher State Educational Institution of Ukraine «Bukovinian State Medical University», Teatralna sq., 2, Chernivtsi, Ukraine, 58002

E-mail: physiology@bsmu.edu.ua

Tetiana Savchuk, PhD, Assistant, Department of Physiology, Higher State Educational Institution of Ukraine «Bukovinian State Medical University», Teatralna sq., 2, Chernivtsi, Ukraine, 58002

E-mail: physiology@bsmu.edu.ua 